\title{
Risk Factors for Transport-Related Problem Behaviors in Horses: A New Zealand Survey
}

\author{
Barbara Padalino ${ }^{1,2, *(1)}$, Chris W. Rogers ${ }^{3}$ (D), Danielle Guiver ${ }^{3}$, Janis P. Bridges ${ }^{3}$ and \\ Christopher B. Riley ${ }^{3}$ (iD \\ 1 College of Veterinary Medicine and Life Sciences, City University of Hong Kong, Kowloon, \\ Hong Kong, China \\ 2 Department of Veterinary Medicine, University of Bari, 70010 Bari, Italy \\ 3 School of Veterinary Science, Massey University, Palmerston North 4470, New Zealand; \\ C.W.Rogers@massey.ac.nz (C.W.R.); Danielle.guiver@gmail.com (D.G.); J.P.Bridges@massey.ac.nz (J.P.B.); \\ C.B.Riley@massey.ac.nz (C.B.R.) \\ * Correspondence: barbara.padalino@cityu.edu.hk or barbara.padalino@uniba.it; Tel.: +86-852-55012560
}

Received: 6 July 2018; Accepted: 31 July 2018; Published: 2 August 2018

Simple Summary: Transport-related problem behaviors (TRPBs) are unwanted behaviors exhibited by horses in one or multiple phases of transport contributing to the injury of the horses and their handlers. The aim of this study was to identify risk factors for TRPBs in support of the development of best practices that minimize their incidence, and safeguard horse and handler wellbeing. An online cross-sectional survey was designed and disseminated to New Zealand equine industry members. Respondents were asked whether one of their horses had shown TRPBs during the two previous years, and to describe their equine background and experience, the method or way in which they had trained their horses for loading and travelling, the type of aids they used for loading and the type of vehicle. At least one horse was reported as showing a TRPB by almost one out of four of respondents. The type of vehicle, of training and of aids used for loading and travelling resulted associated with TRPBs. These findings may be useful to enhance horse welfare by educating people in charge of moving horses on appropriate training methods and vehicle selection for road transportation.

\begin{abstract}
Transport-related problem behaviors (TRPBs) are common in horses and can cause injury to both the horses and their handlers. This study aimed to identify possible risk factors for TRPBs to inform approaches to mitigate TRPBs incidence and enhance horse welfare. An online cross-sectional survey was conducted to explore the prevalence of TRPBs and their association with human-, training- and transport management-related factors in New Zealand. The survey generated 1124 valid responses that were analyzed using descriptive statistics, and logistic regression analyses. Having at least one horse with TRPB was reported by $249 / 1124$ (22.2\%) respondents during the two previous years. Of these, $21 / 249(8.4 \%)$ occurred during pre-loading, 78/249 (31.3\%) during loading, 132/249 $(53.0 \%)$ while travelling, and 18/249 (7.3\%) during unloading. Our findings indicate that the use of negative reinforcement and positive punishment as training methods, using a whip or food for loading, and travelling in a straight load trailer/float while offering food were associated with a higher likelihood of TRPBs. Cross-sectional studies cannot determine causality and findings should be interpreted with caution, and evaluated in further experimental studies. The authors suggest that education on appropriate training methods for transport, and vehicle selection may mitigate the risk for TRPBs in horses.
\end{abstract}

Keywords: problem behavior; transport; training; horse 


\section{Introduction}

Transport-related problem behaviors (TRPBs) are unwanted behaviors exhibited by horses in one or multiple phases of transport [1]. TRPBs have been categorized as associated with pre-loading (e.g., increased vocalizations and pawing), loading (e.g., refusal to load), travelling (e.g., repeated kicking of parts of the vehicle or other horses) and unloading (e.g., rushing off the ramp) [2]. Refusal to load and scrambling (i.e., loss of footing and repeated attempts to keep from falling) en route are the most commonly reported within the literature [3-5]. TRPBs often frustrate horse handlers due to time delays, or inability to transport their horse to the sport event or leisure activity [1]. Injuries to the horse and handler are often reported with TRPBs, compromising welfare and safety [2]. TRPBs and their consequences are apparently common. A recent YouTube search produced more than 67,000 videos related to TRPBs and their possible solutions; many touted solutions did not comply with published evidence-based recommendations [1].

Scientifically based training methods have been studied since the $80 \mathrm{~s}$ and are recommended to mitigate the incidence of TRPBs and their consequences [1,6]. Habituation to loading and travelling is one approach to desensitizing horses to their innate fear of transport vehicles [6]. The technique commences with a series of simulations of loading, staying inside the transport vehicle and unloading until the horse no longer shows anxiety. Short journeys are then undertaken, initially within the property, and then the duration is progressively increased. This training should be carried out before the first real journey. Ideally habituation for transport should start with the foal, following the mare into the truck or trailer. Another method to habituate or desensitize the horse is to leave a transport vehicle in the paddock and to feed the horse inside it [3]. To minimize TRPBs developing in frequent travellers resulting from an association with performance activities, horses should not only experience journeys to official competition, but also to low stress destinations (e.g., pasture) [3]. With the successful implementation of the afore mentioned techniques, loading for transport and travelling should be less stressful for the horse, minimizing the occurrence of TRPBs [7].

Self-loading has also been suggested to train horses to load freely and prevent TRPBs [8]. As per the habituation training, different methods may be used to reach the goal of self-loading and should be performed before a required journey. Frequently suggested methods to teach a horse to self-load are clicker and target training (based on positive reinforcement) $[9,10]$, but other training methods (based on negative reinforcement) are also used [11]. Self-loading requires patience and a combination of operant and classical conditioning that results in a horse that self-loads on command. The cues can be acoustic or visual, such as seeing the open ramp or positioning of the lead rope on the neck [2]. Habituation and self-loading have been found to be associated with lower levels of reported TRPBs, but their use is rarely reported within the literature [1,2,12]. Despite the scientific evidence of describing appropriate methods for training horses [1,2,13], many people may not train their horses for loading and travelling in transport vehicles, or may use inappropriate training methods based solely on negative reinforcement or positive punishment $[2,8,12]$.

In a survey on horse transport management and issues in Australia 38\% of respondents reported having at least one horse with TRPBs [14]. Most did not train their horses for loading and travelling, and TRPBs were associated with training methods, forward-facing trailers, and the use of whip and bum (butt) ropes for loading [2]. A survey on TRPBs has not previously been conducted in New Zealand, and associations with transport management and human-related factors have not been reported. The authors hypothesized that TRPBs were associated with the experience of respondents in horse handling, the type of training for loading and travelling, and transport management factors. The study aimed to identify risk factors for TRPBs in support of the development of best practices that minimize their incidence, and safeguard horse and handler wellbeing.

\section{Materials and Methods}

This online survey-based study was approved by the Massey University Human Ethics Committee as low risk (Ethics Notification Number: 4000017178). 


\subsection{Target Population}

The target population for the survey were New Zealand equine industry participants. Eligible respondents were required to have one or more horses in their care and to be responsible for organizing transport of horses for professional or recreational purposes at least once during the two years prior to completing the survey. For inclusion in this study, the respondent had to respond to the question related to TRPBs (Q.18, Supplementary file). The approximate size of this population was estimated to be $90,000[15,16] .1053$ surveys were therefore required to attain a 95\% confidence level, and an error level of $\pm 5 \%$ [17].

\subsection{Study Design and Data Collection}

A cross-sectional online survey was conducted in New Zealand between 7 February 2017 and 16 May 2017 (about 3 months). The survey was designed taking into account the findings of a survey on transport-related issues and practices recently distributed in Australia [14]. Key survey design features to ensure valid results were considered including a process of iterative review [18,19]. The survey was digitized (Qualtrics, New Zealand) and piloted among six horse owning staff members at Massey University. An invitation letter and the link to the online survey were provided to a wide range of New Zealand horse sports and organizations, and the survey link was also published on equestrian websites related to those organizations. The link was also promoted through a national horse magazine, relevant social media pages and online horse forums [20]. The survey exploring TRPBs contained 18 closed and one open questions (Supplementary file). There were questions about the respondents (gender, equine industry sector in which they were involved; amateur or professional relationship with the horse, experience with horse handling, ability to identify equine distress, number of horses in care), the journey (frequency, duration), transport management (type of vehicle, positioning inside the vehicle, use of sedation and protective equipment pre-journey, type of restraint during transport, presence of food en route), the use of a specific training for loading and travelling, the use of equipment for loading (whip, bum (butt)-rope, food), and experience of a horse showing TRPB (and in what phase of transport).

\subsection{Statistical Analysis}

The contributions of the explanatory variables related to the respondents, the journey and the transport management characteristics (Table 1) were evaluated with respect to the occurrence of TRPBs. To ensure a more balanced dataset (i.e., no category with less than $5 \%$ of the population of values), data from the Thoroughbred and Standardbred racing respondents were combined into the same category, and those reporting "some" or "moderate" ability to assess distress in horses were combined into the same group for analyses.

Respondents were asked to describe the method or way in which they had trained their horses for loading and travelling. The replies were classified by one of the researchers (BP) with expertise in animal training into the following training method categories: habituation $(\mathrm{H})$, self-loading (SL), no identified training (NT), operant conditioning with a combination of negative reinforcement and positive punishment $(\mathrm{R}-\mathrm{P}+)$, and operant conditioning using positive reinforcement $(\mathrm{R}+)($ Table 2) [1]. To be considered as habituation, the respondent had to have specified that the training was applied before a real trip, and repeated several times with the aim to desensitize/get the horses used to the transport procedures. To be considered as SL, the respondent had to have written "self-loading". 
Table 1. Classification of the survey variables.

\begin{tabular}{|c|c|c|}
\hline Name & Description & Values \\
\hline \multicolumn{3}{|c|}{ Respondent characteristics } \\
\hline Gender & Gender of the respondent & Male, Female \\
\hline Sector & Sector of the horse industry in which the respondent was involved & $\begin{array}{l}\text { Thoroughbred or Standardbred racing, Dressage, Eventing, Show Jumping, Pony Club, } \\
\text { Endurance and Competition Trail Riding, Horse breeding, Recreational non-competitive, Other } \\
\text { (i.e., Hunting, Western, Polo, Showing) }\end{array}$ \\
\hline Involvement & Nature of the respondent's involvement with horses & $\begin{array}{l}\text { Professional (involved with horses for financial reward), Amateur (involved with horses as a } \\
\text { hobby or recreationally) }\end{array}$ \\
\hline Experience & Respondent's years of experience handling horses & $1-5,6-10,11-20,21-30,31-40,41-50,>51$ \\
\hline Number of horses & Number of horses kept with their horse described in the survey & $1-2,3-5,6-10,11-15,16-30,>31$ \\
\hline Distress & Respondent's self-assessment of their own ability to identify a horse in distress & 1-none, 2-some or 3-moderate, 4-high, 5-very high \\
\hline \multicolumn{3}{|c|}{ Journey characteristics } \\
\hline Journey frequency & Frequency of organized transport events & Daily, 2-5 times a week, once a week, fortnightly, monthly, <once a month \\
\hline Journey distance & Average journey distance $(\mathrm{km})$ & $1-30,31-60,61-90,91-120,120-240,>241$ \\
\hline \multicolumn{3}{|c|}{ Transport management characteristics } \\
\hline Vehicle & Transport vehicle usually used for moving horses & $\begin{array}{l}\text { Small truck-2 to } 3 \text { horses, Large truck—more than } 3 \text { horses, Gooseneck, Float/trailer-angle } \\
\text { load, Float/trailer-straight load, Use of a commercial trucking company }\end{array}$ \\
\hline Direction & Direction horse is facing during travel & Head facing or angled to the front, Head facing or angled to the rear, Horse free and unrestrained \\
\hline Sedation & Use of sedation or other products to calm the horse(s) prior to transportation & Yes, No \\
\hline $\begin{array}{l}\text { Protective } \\
\text { equipment }\end{array}$ & $\begin{array}{l}\text { Use of one or more items of protective equipment (Leg boots, leg bandage, } \\
\text { pool protector, Tail guard, Neck/Body rug, other) }\end{array}$ & Yes, No \\
\hline Rugs & The use of rug & Yes, No \\
\hline Boots & The use of boots & Yes, No \\
\hline Training & If and how the respondent trained the horse to load, travel and unload & Habituation, Self-loading, operant conditioning $\mathrm{R}-\mathrm{P}+{ }^{1}, \mathrm{R}+{ }^{2}$, no identified training method \\
\hline Whip & The respondent's use of a whip during loading procedure & Yes, No \\
\hline Bum rope & The respondent's use of a bum rope during loading procedure & Yes, No \\
\hline Food & The respondent's use of food during loading procedure & Yes, No \\
\hline Restraint & How the respondent restrained the horse en route & I do not restrain my horse; Tie up on a short rope; Tie up on a long rope; Cross tie \\
\hline Food en route & Did the respondent offer food to the horse(s) when travelling & Yes, No \\
\hline
\end{tabular}


Table 2. Definitions of training categories as modified by Padalino et al. (2017) and examples of respondents' replies for the training category.

\begin{tabular}{|c|c|c|}
\hline Training Category & Definition & $\begin{array}{l}\text { Examples of Typical Responses to the Question: "Have You Use Any } \\
\text { Training to Aid in Transporting Your Horses? If So, Describe the } \\
\text { Training Tool (i.e., Training in Loading and Unloading the Vehicle)" }\end{array}$ \\
\hline Habituation $(\mathrm{H})$ & $\begin{array}{l}\text { The habituation category included techniques used to } \\
\text { habituate horses to all aspects of transport prior to } \\
\text { travel, such as familiarizing young (foals and } \\
\text { weanlings) and new horses to the transport vehicle, } \\
\text { repeated loading and unloading prior to travel, and/or } \\
\text { taking the horses on short trips, and/or using an } \\
\text { experienced companion for short trips prior to } \\
\text { undertaking longer journeys for specific purposes [7]. }\end{array}$ & $\begin{array}{l}\text { 1. Leaving the float in a paddock with food and water inside. } \\
\text { 2. Using food as a reinforcement, gradually encouraging the horse to go } \\
\text { into the float and get used to partitions/bars/ramp, and put in place } \\
\text { before short drives around the block. } \\
\text { 3. Getting them used to walking in and out of a float and standing calmly } \\
\text { with another horse in the float. } \\
\text { 4. Educating them to load from young age, load but don't travel initially, } \\
\text { small trips to begin with monitoring how they are travelling, take a mate } \\
\text { with them to begin with, remove partition in float to start with, feed } \\
\text { reward for loading initially, drive very slowly to begin with; do everything } \\
\text { possible to ensure the first few experiences in travelling are good ones. } \\
\text { 5. Repetition of loading and unloading and then when good, increasing } \\
\text { time spent in moving truck. }\end{array}$ \\
\hline Self-loading (SL) & $\begin{array}{l}\text { Operant conditioning and classical conditioning leading } \\
\text { to the horse self-loading onto the vehicle on a verbal, } \\
\text { visual or other classically conditioned cue }[8,9,21] \text {. }\end{array}$ & $\begin{array}{l}\text { 1. Taught self-loading as usually loading by myself. } \\
\text { 2. Self-loads and unloads. } \\
\text { 3. Have trained horses to self-load and know when they are allowed to } \\
\text { come off the float. } \\
\text { 4. All horses are taught to self-load, stand, have the ramp up and be } \\
\text { clipped up with and without a companion experienced traveller before } \\
\text { taking them on a journey. }\end{array}$ \\
\hline No identified training (NT) & $\begin{array}{l}\text { Respondents did not train their horse to load or travel. } \\
\text { Their horses had already been educated with no } \\
\text { identified method. }\end{array}$ & $\begin{array}{l}\text { No. When I bought my horses they had already been trained. They travel } \\
\text { regularly now. }\end{array}$ \\
\hline
\end{tabular}


Table 2. Cont

\begin{tabular}{|c|c|c|}
\hline Training Category & Definition & $\begin{array}{l}\text { Examples of Typical Responses to the Question: "Have You Use Any } \\
\text { Training to Aid in Transporting Your Horses? If So, Describe the } \\
\text { Training Tool (i.e., Training in Loading and Unloading the Vehicle)" }\end{array}$ \\
\hline $\begin{array}{l}\text { Operant conditioning with a } \\
\text { combination of negative } \\
\text { reinforcement and positive } \\
\text { punishment }(\mathrm{R}-\mathrm{P}+)\end{array}$ & $\begin{array}{l}\text { Negative reinforcement (release of the pressure at the } \\
\text { time of the wanted behavior) or positive punishment } \\
\text { (adding an unpleasant stimulus (whipping, or applying } \\
\text { pressure with the bum rope) at the unwanted behavior) } \\
{[22,23] \text {. }}\end{array}$ & $\begin{array}{l}\text { 1. Pressure and release. } \\
\text { 2. Natural horsemanship pressure and release. } \\
\text { 3. Use of a whip to encourage forward movement. } \\
\text { 4. Tapping on sides. } \\
\text { 5. Andrew McLean method of pressure and release to go forward onto } \\
\text { float/truck [23]. } \\
\text { 6. Bum ropes. } \\
\text { 7. Tap front legs initially to teach loading. } \\
\text { 8. Use a bum rope if required, walk them up lifting a leg at a time. } \\
\text { 9. Andrew Mclean method-pressure and release with whip tapping [23]. } \\
\text { 10. Reward (release of the bum rope pressure) with doing the right thing. } \\
\text { 11. Whatever necessary (bum rope, stallion bit, whip). } \\
\text { 12. Andrew Mclean method of loading until horse is comfortable standing } \\
\text { in float. There really isn't much information about how to train them for } \\
\text { the travelling bit-they really have to learn that on the journey }\end{array}$ \\
\hline $\begin{array}{l}\text { Operant conditioning with use of } \\
\text { positive reinforcement }(\mathrm{R}+)\end{array}$ & $\begin{array}{l}\text { Rewarding the wanted behavior using food or other } \\
\text { pleasant reinforcement }[10,22] \text {. }\end{array}$ & $\begin{array}{l}\text { 1. Equitation science, positive reinforcement. } \\
\text { 2. Slowly and consistent with lots of positive reinforcement. } \\
\text { 3. Slowly walking on, rewarding each step with food, horses learn it is a } \\
\text { safe happy place. } \\
\text { 4. Trained via positive reinforcement with feed to load (very good } \\
\text { orientated). } \\
\text { 5. Positive reinforcement. } \\
\text { 6. R+. }\end{array}$ \\
\hline
\end{tabular}


Based on the respondents' response to the multiple-choice question on the equipment used to load horses, the equipment used was classified into the following categories: food (yes, no), whip (yes, no), bum rope (yes, no). Some respondents reported using a stallion bit (91/1133), bridle (25/1133), load ' $n$ ' tie (10/1133; a proprietary rope system placed around the body of the horse and connected to a lead rope separate from that on the halter), towel (1/1133), or lasso (1/1133), but the frequency of responses for these categories were insufficient for analyses of their possible effects on the behavioral outcome (TRPBs).

Reporting the observation of TRPBs (i.e., if the horse had shown a problem behavior) was used as the binary outcome variable (yes/no). Based on the results of the survey question addressing the outcome variable, TRPBs were classified into: pre-loading (PLPB), loading (LPB), travelling (TPB) and unloading (UPB).

The initial descriptive analysis included the creation of frequency tables and was conducted using Statulor $\beta$ (http:/ / statulator.com/descriptive.html). The statistical software R (R v 3.4.1, 2017 Foundation for Statistical Computing, Vienna, Austria) was used for univariate and multivariable logistic regression analyses.

A model was derived for TRPBs; the outcome was binary (1/0, behavioral problem/nonbehavioral problem). The explanatory variables explored included gender, industry sector, involvement, experience, number of horses, distress, journey frequency, journey distance, vehicle, direction of travel of the horse within the vehicle, sedation, protective equipment, rug, boots, type of training, whip, food, restrain and food en route. Initially univariate logistic regression was performed, and $P$ values were calculated using Wald Test. Each predictor variable returning a $p<0.20$ from the univariate modelling was considered for inclusion in a multivariable model (Table S1). A step-wise backward elimination procedure was then conducted whereby predictive variables were removed until all variables in the final model had a Wald's $p<0.05$ indicating significance. A set of basic diagnostic statistics including fitted and standardized residuals and leverage was examined for adherence to model assumptions. No influential points were detected. The models were compared using ANOVA of deviance function in $\mathrm{R}$, and the model with the lowest Akaike information criterion (AIC) was chosen [24]. The findings are presented as odds ratios (OR) and confidence intervals (95\%CI) for each predictive variable.

\section{Results}

\subsection{Survey Response}

There were 1486 initial logins to the survey, but only $1124(75.6 \%)$ respondents answered the question on the presence or absence of TRPBs, and were therefore considered valid for data analyses. This sample size resulted in a 95\% confidence level, and an error level of $\pm 2.8 \%$ for the study population.

\subsection{Descriptive Statistics of The Predictive and Outcome Variables}

Table 3 is a frequency table showing the results of the survey questions. In the two years before the survey, at least one horse was reported as showing a TRPB by 249/1124 (22.2\%, 95\%CI: 19.7-24.6\%) of respondents. Of these 249 reported TRPBs, $21 / 249$ (8.4\%, 95\%CI: 4.9-11.8\%) were described as occurring during pre-loading, 78/249 (31.3\%, 95\%CI: 25.5-37.1\%) loading, 132/249 (53.0\%, 95\%CI: 46.8-59.1\%) while travelling, and 18/249 (7.3\%, 95\%CI: 4.1-10.5\%) on unloading. 
Table 3. Frequency table of the responses to a survey on horse road transport-related problems behaviors in New Zealand

\begin{tabular}{|c|c|c|c|c|}
\hline Variable Name & Category & Count & Percent & $95 \% \mathrm{CI}$ \\
\hline \multirow{4}{*}{ Gender } & Female & 943 & 84.6 & $82.4-86.7$ \\
\hline & Male & 171 & 15.4 & $13.2-17.5$ \\
\hline & Total & 1114 & 100 & \\
\hline & Missing Values & 10 & 0.9 & \\
\hline \multirow{10}{*}{ Sector } & Dressage & 130 & 11.6 & $9.7-13.4$ \\
\hline & Endurance and Competitive trail riding & 54 & 4.8 & $3.5-6.0$ \\
\hline & Eventing & 119 & 10.6 & $8.8-12.4$ \\
\hline & Horse breeding & 67 & 6.0 & $4.6-7.4$ \\
\hline & Other & 96 & 8.5 & $6.8-10.1$ \\
\hline & Pony club & 78 & 6.9 & $5.4-8.3$ \\
\hline & Racing (Thoroughbred and Standardbred) & 238 & 21.2 & $18.8-23.6$ \\
\hline & Recreational riding & 208 & 18.5 & $16.2-20.7$ \\
\hline & Show jumping & 134 & 11.9 & $10.0-13.8$ \\
\hline & Total & 1124 & 100 & \\
\hline \multirow[t]{4}{*}{ Involvement } & Amateur & 840 & 75.3 & $72.7-77.8$ \\
\hline & Professional & 275 & 24.7 & $22.1-27.2$ \\
\hline & Total & 1115 & 100 & \\
\hline & Missing Values & 9 & 0.8 & \\
\hline \multirow[t]{9}{*}{ Experience } & $1-5$ & 47 & 4.2 & $3.0-5.3$ \\
\hline & $6-10$ & 95 & 8.5 & $6.8-10.1$ \\
\hline & $11-20$ & 268 & 24.0 & $21.4-26.5$ \\
\hline & $21-30$ & 228 & 20.5 & $18.2-22.8$ \\
\hline & $31-40$ & 258 & 23.2 & $20.7-25.6$ \\
\hline & $41-50$ & 149 & 13.4 & $11.3-15.4$ \\
\hline & $>51$ & 69 & 6.2 & $4.7-7.6$ \\
\hline & Total & 1114 & 100 & \\
\hline & Missing Values & 10 & 0.9 & \\
\hline \multirow[t]{8}{*}{ Number of horses } & $1-2$ & 196 & 17.7 & $15.4-19.9$ \\
\hline & $3-5$ & 356 & 32.1 & $29.3-34.8$ \\
\hline & $6-10$ & 232 & 20.9 & $18.5-23.2$ \\
\hline & $11-15$ & 96 & 8.6 & $6.9-10.2$ \\
\hline & $16-30$ & 133 & 12.0 & $10.1-13.9$ \\
\hline & $>31$ & 97 & 8.7 & $7.0-10.3$ \\
\hline & Total & 1110 & 100 & \\
\hline & Missing Values & 14 & 1.2 & \\
\hline \multirow[t]{6}{*}{ Distress } & 5-very high & 587 & 52.3 & $49.3-55.2$ \\
\hline & 4-high & 463 & 41.2 & $38.3-44.1$ \\
\hline & 2-some or 3-moderate & 73 & 6.5 & $5.0-7.9$ \\
\hline & 1 -none & 0 & 0 & \\
\hline & Total & 1123 & 100 & \\
\hline & Missing Values & 1 & 0.1 & \\
\hline \multirow[t]{7}{*}{ Journey frequency } & Daily & 79 & 7.0 & $5.5-8.4$ \\
\hline & 2 to 5 times a week & 280 & 24.9 & $22.4-27.4$ \\
\hline & Once weekly & 275 & 24.5 & $21.9-27.0$ \\
\hline & Fortnightly & 209 & 18.6 & $16.3-20.9$ \\
\hline & Monthly & 127 & 11.3 & 9.4-13.1 \\
\hline & Less than once a month & 154 & 13.7 & $11.6-15.7$ \\
\hline & Total & 1124 & 100 & \\
\hline \multirow[t]{8}{*}{ Journey distance (min) } & $1-30$ & 140 & 12.9 & $10.9-14.9$ \\
\hline & $31-60$ & 315 & 29.1 & $26.3-31.8$ \\
\hline & $61-90$ & 98 & 9.0 & $7.2-10.7$ \\
\hline & $91-120$ & 285 & 26.3 & $23.6-28.9$ \\
\hline & $120-240$ & 81 & 7.5 & 5.9-9.0 \\
\hline & $>241$ & 165 & 15.2 & $13.0-17.3$ \\
\hline & Total & 1084 & 100 & \\
\hline & Missing Values & 40 & 3.5 & \\
\hline
\end{tabular}


Table 3. Cont.

\begin{tabular}{|c|c|c|c|c|}
\hline Variable Name & Category & Count & Percent & $95 \% \mathrm{CI}$ \\
\hline \multirow[t]{7}{*}{ Vehicle } & Float/trailer_angle load & 123 & 11.0 & $9.1-12.8$ \\
\hline & Float/trailer_straight load & 587 & 52.4 & $49.5-55.3$ \\
\hline & Large truck-more than 3 horses & 213 & 19.1 & $16.7-21.4$ \\
\hline & Small truck-2 to 3 horses & 128 & 11.4 & $9.5-13.2$ \\
\hline & Use a commercial trucking company & 68 & 6.1 & $4.6-7.5$ \\
\hline & Total & 1119 & 100 & \\
\hline & Missing Values & 5 & 0.4 & \\
\hline \multirow{4}{*}{ Direction of travel } & Head facing or angled to the front & 842 & 77.5 & $75.0-79.9$ \\
\hline & Head facing or angled to the rear & 244 & 22.5 & $20.0-24.9$ \\
\hline & Total & 1086 & 100 & \\
\hline & Missing Values & 38 & 3.4 & \\
\hline \multirow[t]{4}{*}{ Sedation } & Never & 846 & 75.3 & 72.7-77.8 \\
\hline & Yes & 277 & 24.7 & $22.1-27.2$ \\
\hline & Total & 1123 & 100 & \\
\hline & Missing Values & 1 & 0.1 & \\
\hline \multirow[t]{4}{*}{ Protective equipment } & No & 313 & 28.2 & $30.8-25.6$ \\
\hline & Yes & 797 & 71.8 & $74.4-69.2$ \\
\hline & Total & 1110 & 100 & \\
\hline & Missing Values & 14 & 1.2 & \\
\hline \multirow[t]{4}{*}{ Rugs } & No & 764 & 68.8 & $66.1-71.5$ \\
\hline & Yes & 346 & 31.2 & $28.4-33.9$ \\
\hline & Total & 1110 & 100 & \\
\hline & Missing Values & 14 & 1.2 & \\
\hline \multirow[t]{4}{*}{ Boots } & No & 530 & 47.7 & $44.7-50.6$ \\
\hline & Yes & 580 & 52.3 & $49.4-55.2$ \\
\hline & Total & 1110 & 100 & \\
\hline & Missing Values & 14 & 1.2 & \\
\hline \multirow{7}{*}{ Training } & Habituation & 301 & 29.6 & $26.8-32.4$ \\
\hline & None & 238 & 23.4 & $20.8-26.0$ \\
\hline & $\mathrm{R}-\mathrm{P}+{ }^{1}$ & 281 & 27.6 & $24.8-30.3$ \\
\hline & $\mathrm{R}+{ }^{2}$ & 45 & 4.4 & $3.1-5.6$ \\
\hline & Self-loading & 152 & 15.0 & $12.8-17.1$ \\
\hline & Total & 1017 & 100 & \\
\hline & Missing Values & 107 & 9.5 & \\
\hline \multirow[t]{4}{*}{ Whip at loading } & No & 949 & 84.7 & $82.5-86.8$ \\
\hline & Yes & 171 & 15.3 & $13.2-17.4$ \\
\hline & Total & 1120 & 100 & \\
\hline & Missing Values & 4 & 0.35 & \\
\hline \multirow[t]{3}{*}{ Bum rope at loading } & No & 893 & 79.4 & $77.0-81.7$ \\
\hline & Yes & 231 & 20.6 & $18.2-22.9$ \\
\hline & Total & 1124 & 100 & \\
\hline \multirow[t]{4}{*}{ Food at loading } & No & 860 & 76.7 & $74.2-79.1$ \\
\hline & Yes & 261 & 23.3 & $20.8-25.7$ \\
\hline & Total & 1121 & 100 & \\
\hline & Missing Values & 3 & 0.3 & \\
\hline \multirow[t]{6}{*}{ Restraint } & Cross tie & 34 & 3.0 & $1.9-4.0$ \\
\hline & I do not restrain my horse & 124 & 11.1 & $9.2-12.9$ \\
\hline & Tie up on a long rope & 236 & 21.2 & $18.8-23.5$ \\
\hline & Tie up on a short rope & 721 & 64.7 & $61.9-67.5$ \\
\hline & Total & 1115 & 100 & \\
\hline & Missing Values & 9 & 0.8 & \\
\hline \multirow[t]{4}{*}{ Food en route } & No & 755 & 67.8 & $65.1-70.5$ \\
\hline & Yes & 358 & 32.2 & $29.4-34.9$ \\
\hline & Total & 1113 & 100 & \\
\hline & Missing Values & 11 & 1.0 & \\
\hline
\end{tabular}




\subsection{Univariate and Multivariable Logistic Regression}

The results of the univariate logistic regression analyses are presented in Table 4. Respondents with less than 5 years of experience in horse handling, and those claiming a high ability to identify distress in horses were more likely to report a horse with TRPBs. Higher odds of TRPBs was found for horses transported in straight load trailers/floats and by commercial trucking companies, those trained using R-P+, loaded using a whip or food, restrained using a long rope, or fed en route.

Table 4. Results of univariate logistic regression analyses of associations between TRPBs and the explanatory variables, experience in horse handling, ability to recognize distress in horses, vehicle, type of training used to teach horses to load and travel, use of the whip or food at loading, type of restraint and feeding en route. Data were collected from an online survey on horse road transport in New Zealand $(n=1124)$ for movements occurring between 2015 and 2017 (OR: odds ratios; CI: confidence intervals; $P^{\mathrm{a}}$ : LRT $P$ value; $\mathrm{P}^{\mathrm{b}}$ : Wald test $P$ value).

\begin{tabular}{|c|c|c|c|c|c|c|c|}
\hline Variable & Category & $\begin{array}{c}\text { TRPB-No } \\
n(\%)\end{array}$ & $\begin{array}{c}\text { TRPB_-Yes } \\
n(\%)\end{array}$ & OR & $95 \% \mathrm{CI}$ & $\mathbf{P}^{\mathbf{a}}$ & $\mathbf{P}^{\mathbf{b}}$ \\
\hline \multirow{7}{*}{ Experience } & $>51$ & $59(85.5)$ & $10(14.5)$ & Ref & & & \multirow{7}{*}{0.022} \\
\hline & $41-50$ & $125(83.5)$ & $24(16.1)$ & 1.13 & $0.50-2.52$ & 0.766 & \\
\hline & $31-40$ & $206(79.8)$ & $52(20.2)$ & 1.49 & $0.71-3.10$ & 0.301 & \\
\hline & $21-30$ & $169(74.1)$ & $59(25.9)$ & 2.06 & $0.99-4.28$ & 0.060 & \\
\hline & $11-20$ & $195(72.8)$ & $73(27.2)$ & 2.21 & $1.00-4.54$ & 0.036 & \\
\hline & $6-10$ & $79(83.2)$ & $16(16.8)$ & 1.19 & $0.50-2.82$ & 0.692 & \\
\hline & $1-5$ & $33(70.25)$ & $14(29.8)$ & 2.50 & $1.1-6.25$ & 0.049 & \\
\hline \multirow{3}{*}{ Distress $^{1}$} & 5-very high & $477(81.3)$ & $110(18.7)$ & Ref & & & \multirow{3}{*}{0.010} \\
\hline & 4-high & $340(73.45)$ & $123(26.6)$ & 1.57 & $1.17-2.10$ & 0.002 & \\
\hline & 3,2 -moderate, some & $57(78.1)$ & $16(18.7)$ & 1.22 & $0.67-2.19$ & 0.514 & \\
\hline \multirow{5}{*}{ Vehicle } & Small truck-2 to 3 horses & $113(88.3)$ & $15(11.7)$ & Ref & & & \multirow{5}{*}{0.003} \\
\hline & $\begin{array}{c}\text { Float/trailer—straight } \\
\text { load }\end{array}$ & $434(73.9)$ & $153(26.1)$ & 2.66 & $1.50-4.69$ & $<0.001$ & \\
\hline & Float/trailer-angle load & $101(82.1)$ & $22(17.9)$ & 1.64 & $0.80-3.33$ & 0.171 & \\
\hline & $\begin{array}{c}\text { Large truck-more than } 3 \\
\text { horses }\end{array}$ & $173(81.2)$ & $40(18.8)$ & 1.74 & $0.91-3.29$ & 0.089 & \\
\hline & $\begin{array}{l}\text { Use a commercial } \\
\text { trucking company }\end{array}$ & $50(73.5)$ & $18(26.5)$ & 2.71 & $1.26-5.80$ & 0.010 & \\
\hline \multirow{5}{*}{ Training } & Habituation & $241(80.1)$ & $60(19.9)$ & Ref & & & \multirow{5}{*}{0.021} \\
\hline & Self-loading & $123(80.9)$ & $29(19.1)$ & 0.95 & $0.57-1.55$ & 0.829 & \\
\hline & None & $190(79.8)$ & $48(20.2)$ & 1.01 & $0.66-1.55$ & 0.946 & \\
\hline & $\mathrm{R}-\mathrm{P}+{ }^{2}$ & $197(70.1)$ & $84(29.9)$ & 1.71 & $1.17-2.50$ & 0.006 & \\
\hline & $\mathrm{R}+{ }^{3}$ & $34(75.6)$ & $11(24.4)$ & 1.30 & $0.62-2.70$ & 0.484 & \\
\hline \multirow{2}{*}{$\begin{array}{l}\text { Whip at } \\
\text { loading }\end{array}$} & No & 758 (79.9) & $191(20.1)$ & Ref & & & \multirow[b]{2}{*}{$<0.001$} \\
\hline & Yes & $113(66.1)$ & $58(33.9)$ & 2.04 & $1.43-2.90$ & $<0.001$ & \\
\hline \multirow{2}{*}{$\begin{array}{l}\text { Food at } \\
\text { loading }\end{array}$} & No & $694(80.7)$ & $166(19.3)$ & Ref & \multirow{2}{*}{\multicolumn{2}{|c|}{$1.43-2.65$}} & \\
\hline & Yes & $178(62.2)$ & $83(31.8)$ & 1.95 & & & \\
\hline \multirow{4}{*}{ Restrain } & Tied up on a short rope & $581(80.6)$ & $140(19.4)$ & Ref & & & \multirow{4}{*}{0.022} \\
\hline & I do not restrain my horse & $93(75.0)$ & $31(25.0)$ & 1.38 & $0.88-2.15$ & 0.153 & \\
\hline & Tied up on a long rope & $171(72.5)$ & $65(27.5)$ & 1.57 & $1.12-2.21$ & 0.008 & \\
\hline & Cross tied & $23(67.6)$ & $11(32.4)$ & 1.98 & $0.94-4.10$ & 0.069 & \\
\hline \multirow{2}{*}{$\begin{array}{l}\text { Food en } \\
\text { route }\end{array}$} & No & $619(81.9)$ & $136(18.1)$ & Ref & & & \multirow[b]{2}{*}{$<0.001$} \\
\hline & Yes & $249(65.6)$ & $109(30.4)$ & 1.99 & $1.48-2.66$ & $<0.001$ & \\
\hline
\end{tabular}

${ }^{1}$ No respondents chose option "1-none"; ${ }^{2} \mathrm{R}-\mathrm{P}+$ : operant conditioning with a combination of negative reinforcement and positive punishment; ${ }^{3} \mathrm{R}+$ : operant conditioning using positive reinforcement.

The results of the multivariable logistic regression analyses $\left(\chi^{2}=60.3, \mathrm{df}=11, p<0.001\right)$ are reported in Table 5. Horses transported in a straight load float/trailer, a large truck, or using a commercial company were at higher risk of showing TRPBs in comparison with horses transported in small trucks (2-3 horses). Compared with habituation, the only training method which increased the risk of TRPBs was operant conditioning with the use of negative reinforcement and positive punishment $(\mathrm{R}-\mathrm{P}+)$. The use of whip and food during loading and the practice of feeding the horse en route were also associated with higher odds of TRPBs. 
Table 5. Results of multivariable regression analysis of associations between TRPBs and the explanatory variables, experience, industry sector, and type of involvement (amateur/professional). Data were collected from an online survey on horse road transport in New Zealand $(n=1124)$ for movements occurring between 2015 and 2017 (SE: standard error; OR: odds ratio; CI: confidence intervals; Pa: LRT $P$ value; $\mathrm{P}^{\mathrm{b}}$ : Wald test $P$ value).

\begin{tabular}{|c|c|c|c|c|c|c|c|}
\hline Variable & Category & Estimate & SE & OR & $95 \% \mathrm{CI}$ & $\mathbf{P}^{\mathbf{a}}$ & $\mathbf{P}^{\mathbf{b}}$ \\
\hline Intercept & & -2.5886 & 0.335 & 0.08 & $0.04-0.14$ & $<0.001$ & \\
\hline \multirow{4}{*}{ Vehicle } & $\begin{array}{l}\text { Small truck-2 to } 3 \text { horses } \\
\text { Large truck-more than } 3 \text { horses }\end{array}$ & $\begin{array}{c}\text { Ref } \\
0.862\end{array}$ & 0.355 & 2.37 & $1.21-4.91$ & 0.015 & \multirow{4}{*}{0.005} \\
\hline & $\begin{array}{l}\text { Use a commercial trucking } \\
\text { company }\end{array}$ & 1.379 & 0.429 & 3.97 & $1.72-9.35$ & 0.001 & \\
\hline & Float/trailer—angle load & 0.602 & 0.388 & 1.82 & $0.86-3.99$ & 0.121 & \\
\hline & Float/trailer—straight load & 1.034 & 0.318 & 2.81 & $1.56-5.47$ & 0.001 & \\
\hline \multirow{5}{*}{ Training } & Habituation & Ref & & & & & \multirow{5}{*}{0.035} \\
\hline & None & -0.124 & 0.227 & 0.88 & $0.56-1.38$ & 0.585 & \\
\hline & Self-loading & -0.246 & 0.267 & 0.78 & $0.46-1.31$ & 0.356 & \\
\hline & $\mathrm{R}-\mathrm{P}+{ }^{1}$ & 0.416 & 0.206 & 1.52 & $1.01-2.27$ & 0.043 & \\
\hline & $\mathrm{R}+{ }^{2}$ & -0.164 & 0.406 & 0.85 & $0.37-1.83$ & 0.686 & \\
\hline \multirow[b]{2}{*}{ Food } & No & Ref & & & & & \multirow[b]{2}{*}{0.024} \\
\hline & Yes & 0.413 & 0.184 & 1.05 & $1.05-2.16$ & 0.024 & \\
\hline \multirow{2}{*}{ Whip } & No & Ref & & & & & \multirow[b]{2}{*}{0.031} \\
\hline & Yes & 0.435 & 0.202 & 1.04 & $1.04-2.29$ & 0.031 & \\
\hline \multirow{2}{*}{$\begin{array}{l}\text { Food en } \\
\text { route }\end{array}$} & No & Ref & & & & & \multirow[b]{2}{*}{$<0.001$} \\
\hline & Yes & 0.635 & 0.165 & 1.89 & $1.37-2.61$ & $<0.001$ & \\
\hline
\end{tabular}

${ }^{1} \mathrm{R}-\mathrm{P}+$ : operant conditioning with a combination of negative reinforcement and positive punishment; ${ }^{2} \mathrm{R}+$ : operant conditioning using positive reinforcement.

\section{Discussion}

This cross-sectional study documented the prevalence of TRPBs in horses transported in New Zealand for pleasure or professional purposes, and for the first time explored associations between TRPBs, and human- and transport management- factors. This study is the first to identify a relationship between TRPBs and management-related factors such as horse handling experience, the ability to recognize distress in horse, appropriate transport-related training methods, the use of whip during loading, the type of restraint used in transit, and the use of feeding during loading and en route. These data support the authors' hypotheses. However, the findings of surveys rely upon the retrospective recollection of participants, and should not be construed as defining causal relationships among factors [25]. It is worth highlighting that the detailed nature of the relationships identified between TRPBs and transport management routines in this study cannot be precisely defined. The latter is a common limitation of all studies exploring management factors and based on survey methods $[25,26]$. For instance, management practices may have been applied in attempts to minimize TRPBs rather than being causative factors. For example, the associations between TRPBs and the practices of feeding and restraint with a long rope en route are more likely a reflection of owners' attempts to implement better practices, and require empirical further research.

Our findings documented characteristics of people involved in the care and transport of horses in New Zealand and their transport practices. In agreement with other studies, most of our respondents were women taking care of fewer than five horses in their property, involved with horses as amateur mainly in equestrian sports or pleasure activities, moving horses frequently and on short distance [27-29]. As described in Australia, the transport vehicle most frequently used was a two-horse straight load trailer (float) with the horse facing in a forward direction of travel, and boots were the most frequently used protective equipment [14]. Even though wearing a rug, cross-tying or tying on a short rope en route have been discouraged as inconsistent with best practice [30], one third of the respondents applied these practices. On the other hand, it is worth highlighting that New Zealanders associated with horse transport appear (based on the survey data) to understand 
the importance of training horses for loading and travelling [7]. The data suggest that New Zealand respondents more commonly train their horses than Australians involved in horse transport $(80 \%$ versus $40 \%$ ) [14]. In particular, habituation and positive reinforcement training were more often used by horse owners/trainers in New Zealand compared to horse owners/trainers in Australia [2]. However, whips and bum ropes were more frequently used as aid to load horses than reported in Australia [2]. In New Zealand one out of three respondents documented feeding their horses en route. This practice was more frequently applied in Australia [14] and may be related to the longer distances generally travelled by horses in Australia. Whether feeding en route is or is not best practice, it is still a matter of debate within the literature.

Overall, the rate of TRPBs was lower in New Zealand than in Australia (38.6\%) [14]. In contrast with the literature, New Zealand respondents recalled having more TRPBs in transit than when loading horses; loading has been associated more frequently with TRPBs in many other studies $[1,2,4]$. These differences may reflect the populations of respondents with respect to their demographic, cultural backgrounds and perception of TRPBs. It may also lie in the type of journey, the different transport management practices and particularly in the different training practices used. Most of our respondents used training methods, such as SL or operant conditioning, focused on teaching horses how to load. This may explain why the prevalence of loading TRPBs was less common than those encountered in transit.

The Australian, New Zealand and European codes of animal transport [31-33] recommend that horses should be loaded by people with proven experience in horse handling. A course on how to identify and manage stress in the transported animals is mandatory in Europe for any commercial journey [31], but not in New Zealand. This study is the first to confirm an association between less experience (particularly less than five years) in horse handling, and less ability to identify horse distress with higher odds of TRPBs, adding scientific evidence for the recommendations contained within these animal transport codes. While TRPBs have been associated with a higher risk of injury to horses [2], training to increase horse handling skills and understanding of horse behavior is recommended to minimize the incidence of TRPBs and their consequences in New Zealand.

The findings described in the current report demonstrate an association of TRPBs with straight load trailers, confirming results reported in a previous study [2]. Loading in a small and dark two-horse straight load trailer has been described as an unpleasant and frightening experience for any horse, taking into account the equine field of vision [13]. Straight load trailers are less wide than angle or backward facing loading trailers, which have been suggested to be less frightening and easier to load horses into [34]. The width of space allocated to the horses in transit may affect their stress responses. Stull et al. [35] demonstrated that rectal temperature, white blood cell count, cortisol level and neutrophil-lymphocytes ratio were higher in horses travelling in straight deck trailers $\left(1.14 \mathrm{~m}^{2}\right)$ than in pot-belly trailers $\left(1.31 \mathrm{~m}^{2}\right)$. Furthermore, as both loading and travelling problems were considered in our dataset, one reason for the association may be because a forward-facing position was found to be less preferred and unstable in comparison with sideways and backward travel [36-38]. Consequently, travelling in a straight load trailer may be more likely to cause scrambling and other TRPBs. The authors also found an association with large trucks and with the movement of horses in commercial company trucks. This finding is new and requires further exploration. Factors for consideration may include the effect of the angle of the loading ramp, often steeper for these types of trucks, and the effect of loading into a new environment where there are more likely to be non-familiar horses that were already loaded at other points of departure. Although further studies are required, it is possible that horses transported in these types of vehicles are more likely to encounter non-familiar horses, increasing the risk of social stress on horses, and causing more aggressive behavior (biting or kicking other horses) and other problem behaviors in transit which were more frequently reported in comparison to loading problems by the respondents in the current study. Horses transported in commercial trucks spend the first hour of their journey sniffing and exploring the new environment, reporting the highest frequency of stress-related behaviors in the first hour, and showing aggressive 
behaviors toward non-familiar neighbors in the last part of the journey [39]. It is possible that these stress-related and aggressive behaviors were interpreted and reported as TRPBs by our respondents. The use of video cameras to monitor behavior during commercial transportation is mandatory in Europe and is recommended in commercial and non-commercial transportation to clarify the nature of travelling problem behaviors, and provided indications to minimize their consequences. In European commercial transportation, horses are only allowed to be transported in vehicles equipped with solid dividers that go all the way to the ground. In our survey there were no questions about the type of dividers and other features of trailer design. Further studies are needed to explore the possible associations between the features of trailer design and TRPBs.

This manuscript provides evidence confirming that the use of training based on negative reinforcement and positive punishment is not consistent with best practice for teaching horses to load and travel [1]. In the case of a horse that refuses to load, the use of operant conditioning based on negative reinforcement (i.e., the release of the pressure) often fails. This is because the pressure is frequently released when the horse forcefully moves away from the ramp, overcoming the strength of the human handler [2]. Therefore, negative reinforcement should not be used because in this situation the horse learns that it can "win the battle pressure against pressure" [13]. The use of positive punishment such as whipping has been already described by Houpt (1982) as a method which can momentarily solve the problem (i.e., the horse loads to avoid whipping), but creates a negative association (i.e., trailer loading equals being whipped). Subsequently, the next time transport is attempted, the horse misbehaves at the view of the trailer, increasing the odds of TRPBs at loading. Whipping at loading may also increase the risk of TRPBs in transit, because the horse loads with a higher level of fear and anxiety, and starts to show TRPBs while the vehicle is moving [1]. The findings of the current study agree with the literature, with the use of a whip at loading increasing twofold the likelihood of TRPBs being reported. Food has been described as a tool for positive reinforcement recommended to retrain horses with loading problems [10]. In contrast, for the current study the use of food during loading was associated with a higher likelihood of TRPBs being reported. There are several possible explanations for this finding. A first consideration is that positive reinforcement has been shown to be less effective in the presence of stressors, because learning performance is impaired [40]. Secondly, it is possible that respondents may have used food inappropriately to motivate the horse to load rather than as a proper reward given in response to the wanted behavior [41]. Finally, it is possible that respondents used food at loading in attempts to minimize TRPBs; positive reinforcement may have been indeed given to treat TRPBs rather than causing them. As mentioned above, the nature of the associations found using this type of surveys cannot precisely defined. A limitation of the current study is that training with respect to TRPBs was considered without distinguishing among pre-loading, loading, travelling and unloading problem behaviors as was previously described by Padalino et al. [2]. The latter authors reported that habituation was the only method which minimized the risk of any type of TRPBs, self-loading decreased only TRPBs at loading and unloading and operant conditioning increased all type of TRPBs. The current study suggests that negative reinforcement and positive punishment, particularly using a whip, are more likely to increase the prevalence of TRPBs and are not recommended to train horses for loading and travelling. However, a prospective study with a more critical evaluation of the effects of different types of training on the prevention or management of TRPBs would be of value.

In the current study feeding while travelling, and the use of a long rope for restraint were associated in the univariate regression with an increased likelihood of TRPBs. The effects of the feeding and restraint en route on the risk of transport-related respiratory disease have been evaluated in previous studies [42-45]. No restraint or the use of a long rope, and positioning food at least at the knee level have been recommended to mitigate the risk of transport pneumonia [41-44]. The effects of the type of restraint and feeding en route on TRPBs have not previously been described in the literature. Many horse owners believe that offering food en route calms horses, and less restraint allows the horse to meet postural corrections when the vehicle is slowing down [34]. These practices could have 
therefore used in the attempt to reduce the incidence of TRPBs and cannot be interpreted as a cause of TRPBs, as afore mentioned [26]. Overall, our findings should be considered preliminary and the effects of travelling with the presence of food, its position and type should also be tested in the future to clarify their effects on transport-related health and behavioral problems.

In the final multivariable model, the type of vehicle used for horse transport, the training used for loading and travelling, the use of whip and food during loading, and the presence of food en route remained as the most significant factors associated with TRPBs. These findings highlighted the importance of educating people in charge of moving horses to read horse body language, and understand animal learning principles (which are the basis of a correct horse handling in equitation science) $[22,40]$. Unfortunately, there are no evidence-based design standards for the design of horse trailers used for non-commercial transport in New Zealand and most other countries [34]. More research is needed to better understand what type of vehicle design (e.g., bay space, positioning, lights) may decrease transport stress and TRPBs in horses.

The findings from the study should be interpreted with caution for the reasons outlined above. Although survey respondents were asked about initial training for loading and travelling, it was difficult to differentiate whether the respondents reported their initial training for transport or the retraining methods used to treat horses showing TRPBs. The author suggests that our findings about the training methods should not be applied to horses suffering from established TRPBs, and that these animals undergo an appropriate retraining plan as suggested in the literature $[8,10]$. Notwithstanding the limitations of the survey, this study was useful for identifying human, management and training factors which were associated with TRPBs and for providing a basis for the development of prospective studies. The application of these findings and subsequent research may be useful for enhancing the wellbeing and safety of the horse and its handler during transport.

\section{Conclusions}

This study is the first to identify associations between TRPBs and human-, training- and transport management factors in New Zealand. Among human factors, experience in horse handling and the ability of the horse handler to recognize distress were associated with lower odds of TRPBs. Regarding training for loading and travelling, habituation was confirmed as the preferred method to minimize the prevalence of TRPBs. The two-horse straight load trailer was confirmed as the transport vehicle most likely to be associated with a higher likelihood of TRPBs. The other associations found need to be confirmed with further studies. The findings of this study add to the knowledge base that can be used to educate people involved in horse transportation, to decrease the risk of TRPBs, to safeguard horse welfare and safety of the horse handler during transport.

Supplementary Materials: The following are available online at http:/ /www.mdpi.com/2076-2615/8/8/134/s1. Table S1: Univariate logistic regression Wald's test $P$ values calculated with TRPBs as outcome. Supplementary file: Survey used in the study.

Author Contributions: Conceptualization, B.P. and C.B.R.; Methodology, B.P., D.G. and C.B.R.; Software, D.G., and C.B.R.; Validation, B.P., D.G. and C.B.R.; Formal Analysis, J.P.B.; Investigation, D.G., C.W.R. and C.B.R.; Resources, C.B.R.; Data Curation, B.P. and J.B.; Writing-Original Draft Preparation, B.P.; Writing-Review \& Editing, C.W.R. and C.B.R.; Visualization, C.B.R.; Supervision, C.B.R.; Project Administration, C.B.R.; Funding Acquisition, C.B.R.

Funding: This research was funded by grants from the Eminent Visitors Program at Massey University and the Massey University International Visitors Research Fund and by a summer scholarship from the New Zealand Equine Trust.

Acknowledgments: The authors would like to thank the associations and institutions which helped in distribution of the survey, and the respondents, who gave their time to respond in the on line survey. This project would not have been possible without their voluntary contribution.

Conflicts of Interest: The authors declare no conflict of interest. 


\section{References}

1. Yorke, A.; Matusiewicz, J.; Padalino, B. How to minimise the incidence of transport-related problem behaviors in horses: A review. J. Equine Sci. 2017, 28, 67-75. [CrossRef] [PubMed]

2. Padalino, B.; Henshall, C.; Raidal, S.L.; Knight, P.; Celi, P.; Jeffcott, L.; Muscatello, G. Investigations into equine transport-related problem behaviors: Survey results. J. Equine Vet. Sci. 2017, 48, 166-173. [CrossRef]

3. Houpt, K.A. Stable vices and trailer problems. Vet. Clin. N. Am. Equine Pract. 1986, 2, 623-633. [CrossRef]

4. Lee, J.; Houpt, K.; Doherty, O. A survey of trailering problems in horses. J. Equine Vet. Sci. 2001, 21, $235-238$. [CrossRef]

5. Riley, B.C.; Noble, R.B.; Bridges, J.; Hazel, J.S.; Thompson, K. Horse injury during non-commercial transport: Findings from researcher-assisted intercept surveys at southeastern Australian equestrian events. Animals 2016, 6, 65. [CrossRef] [PubMed]

6. Houpt, K. Misbehavior of horses: Trailer problems. Equine Pract. 1982, 4, 12-16.

7. Houpt, K.A.; Wickens, C.L. Handling and transport of horses. In Livestock Handling and Transport, 4th ed.; CABI: Wallingford, Oxfordshire, UK, 2014; pp. 315-341.

8. Ferguson, D.L.; Rosales-Ruiz, J. Loading the problem loader: The effect of target training and shaping on trailer-loading behavior of horses. J. Appl. Behav. Anal. 2001, 34, 409-423. [CrossRef] [PubMed]

9. Bruce, G. How to Click with Your Horse: Clicker Training for Groundwork, Riding E Problem Solving/by Georgina Bruce; Photos by Ron Bruce; Illustrations by Georgina Bruce; Click With Horses: Kuranda, Queensland, Australia, 2009.

10. Hendriksen, P.; Elmgreen, K.; Ladewig, J. Trailer-loading of horses: Is there a difference between positive and negative reinforcement concerning effectiveness and stress-related signs? J. Vet. Behav. 2011, 6, 261-266. [CrossRef]

11. Parelli, P.; Kadash, K.; Parelli, K. Natural Horse-Man-Ship; Western Horseman: Colorado Springs, CO, USA, 1993.

12. Yngvesson, J.; De Boussard, E.; Larsson, M.; Lundberg, A. Loading horses (Equus caballus) onto trailers-behavior of horses and horse owners during loading and habituating. Appl. Anim. Behav. Sci. 2016, 184, 59-65. [CrossRef]

13. McGreevy, P. Equine Behavior: A Guide for Veterinarians and Equine Scientists, 2nd ed.; Elsevier: New York, NY, USA, 2012.

14. Padalino, B.; Raidal, S.; Hall, E.; Knight, P.; Celi, P.; Jeffcott, L.; Muscatello, G. Survey of horse transportation in Australia: Issues and practices. Aust. Vet. J. 2016, 94, 349-357. [CrossRef] [PubMed]

15. Anon. Size and Scope of the New Zealand Racing Industry; New Zealand Racing Board: Wellington, New Zealand, 2010.

16. Matheson, A.; Akoorie, M.E. Economic Impact Report on the New Zealand Sport Horse Industry; The University of Waikato: Hamilton, New Zealand, 2012.

17. Custom Insight. Survey Random Sample Calculator. Available online: http://www.custominsight.com/ articles/random-sample-calculator.asp (accessed on 6 December 2012).

18. Dean, R. The use and abuse of questionnaires in veterinary medicine. Equine Vet. J. 2015, 47, 379-380. [CrossRef] [PubMed]

19. Christley, R. Questionnaire survey response rates in equine research. Equine Vet. J. 2016, 48, 138-139. [CrossRef] [PubMed]

20. Padalino, B.; Rogers, C.W.; Thompson, K.; Riley, B.C. Human factors contributing to the risk of equine road transport injury in New Zealand. Anim. Prod. Sci. 2018, submitted.

21. McLean, A. The Truth about Horses; Penguin: Camberwell, Victoria, Australia, 2003.

22. Baragli, P.; Padalino, B.; Telatin, A. The role of associative and non-associative learning in the training of horses and implications for the welfare (a review). Ann. Ist. Super. Sanit. 2015, 51, 40-51.

23. McGreevy, P.D.; McLean, A. Equitation Science; Wiley: Hoboken, NJ, USA, 2011.

24. Field, A.; Miles, J.; Field, Z. Discovering Statistics Using R; Sage publications: Thousand Oaks, CA, USA, 2012.

25. Hockenhull, J.; Creighton, E. Management practices associated with owner-reported stable-related and handling behavior problems in UK leisure horses. Appl. Anim. Behav. Sci. 2014, 155, 49-55. [CrossRef]

26. Cohen, N.D.; O'Conor, M.S.; Chaffin, M.K.; Martens, R.J. Farm characteristics and management practices associated with development of Rhodococcus equipneumonia in foals. J. Am. Vet. Med. Assoc. 2005, 226, 404-413. [CrossRef] [PubMed] 
27. Rosanowski, S.M.; Cogger, N.; Rogers, C.W.; Bolwell, C.F.; Benschop, J.; Stevenson, M.A. Analysis of horse movements from non-commercial horse properties in New Zealand. N. Z. Vet. J. 2013, 61, 245-253. [CrossRef] [PubMed]

28. Rosanowski, S.; Cogger, N.; Rogers, C.; Benschop, J.; Stevenson, M. A description of the demographic characteristics of the New Zealand non-commercial horse population with data collected using a generalised random-tessellation stratified sampling design. Prev. Vet. Med. 2012, 107, 242-252. [CrossRef] [PubMed]

29. Rogers, C.W.; Gee, E.; Bolwell, C. Horse production. In Livestock Production in New Zealand; Stafford, K., Ed.; Massey University Press: Auckland, New Zealand, 2017.

30. Cregier, S.E. Best practices: Surface transport of the horse. In Proceedings of the Animal Transportation Association, AATA Education Committee, Vancouver, BC, Canada, 14 December 2009; pp. 1-29.

31. Eur-Lex. Available online: http://eur-lex.europa.eu/legal-content/EN/TXT/?uri=uriserv:f83007 (accessed on 1 October 2015).

32. Land Transport. Available online: http://www.animalwelfarestandards.net.au/land-transport/ (accessed on 1 October 2015).

33. National Animal Welfare Advisory Committee. Animal Welfare (Transport within New Zealand) Code of Welfare 2011; National Animal Welfare Advisory Committee: Wellington, New Zealand, 2011.

34. Cregier, S.E.; Gimenez, R. Non-Commercial Horse Transport: New Standard for Trailer in Canada; Cregier S: Montague, PE, Canada, 2015.

35. Stull, C. Responses of horses to trailer design, duration, and floor area during commercial transportation to slaughter. J. Anim. Sci. 1999, 77, 2925-2933. [CrossRef] [PubMed]

36. Padalino, B.; Maggiolino, A.; Boccaccio, M.; Tateo, A. Effects of different positions during transport on physiological and behavioral changes of horses. J. Vet. Behav. 2012, 7, 135-141. [CrossRef]

37. Roberts, T. Staying upright in a moving trailer. Equine Athlete 1990, 3, 1-8.

38. Gibbs, A.; Friend, T. Horse preference for orientation during transport and the effect of orientation on balancing ability. Appl. Anim. Behav. Sci. 1999, 63, 1-9. [CrossRef]

39. Padalino, B.; Raidal, S.L.; Knight, P.; Celi, P.; Jeffcott, L.; Muscatello, G. behavior during transportation predicts stress response and lower airway contamination in horses. PLoS ONE 2018, 13, e0194272. [CrossRef] [PubMed]

40. Valenchon, M.; Lévy, F.; Moussu, C.; Lansade, L. Stress affects instrumental learning based on positive or negative reinforcement in interaction with personality in domestic horses. PLoS ONE 2017, 12, e0170783. [CrossRef] [PubMed]

41. McLean, A.N.; Christensen, J.W. The application of learning theory in horse training. Appl. Anim. Behav. Sci. 2017, 190, 18-27. [CrossRef]

42. Stull, C.L.; Rodiek, A.V. Effects of cross-tying horses during 24 h of road transport. Equine Vet. J. 2002, 34, 550-555. [CrossRef] [PubMed]

43. Raidal, S.L.; Love, D.N.; Bailey, G.D. Effects of posture and accumulated airway secretions on tracheal mucociliary transport in the horse. Aust. Vet. J. 1996, 73, 45-49. [CrossRef] [PubMed]

44. Oikawa, M.; Hobo, S.; Oyamada, T.; Yoshikawa, H. Effects of orientation, intermittent rest and vehicle cleaning during transport on development of transport-related respiratory disease in horses. J. Comp. Pathol. 2005, 132, 153-168. [CrossRef] [PubMed]

45. Allano, M.; Labrecque, O.; Batista, E.R.; Beauchamp, G.; Bédard, C.; Lavoie, J.-P.; Leclere, M. Influence of short distance transportation on tracheal bacterial content and lower airway cytology in horses. Vet. J. 2016, 214, 47-49. [CrossRef] [PubMed]

(C) 2018 by the authors. Licensee MDPI, Basel, Switzerland. This article is an open access article distributed under the terms and conditions of the Creative Commons Attribution (CC BY) license (http:/ / creativecommons.org/licenses/by/4.0/). 